\title{
Influence of protein fermentation and carbohydrate source on in vitro methane production
}

\author{
J. L. Vanegas, J. Gonzalez and M. D. Carro
}

Incubations were carried out with batch cultures of ruminal micro-organisms from sheep to analyse the influence of the $\mathrm{N}$ source on in vitro $\mathrm{CH}_{4}$ production. The two substrates were mixtures of maize starch and cellulose in proportions of 75:25 and 25:75 (STAR and CEL substrates, respectively), and the three nitrogen (N) sources were ammonia $\left(\mathrm{NH}_{4} \mathrm{Cl}\right)$, casein $(\mathrm{CA})$ and isolated soya bean protein $(\mathrm{SP})$. Five isonitrogenous treatments were made by replacing non-protein-N (NPN) with CA or SP at levels of 0 (NPN), 50 (CA50 and SP50, respectively) and $100 \%$ (CAl00 and SP100) of total N. All N treatments were applied at a rate of $35 \mathrm{mg}$ of N/g of substrate organic matter and incubations lasted $16.5 \mathrm{~h}$. With both proteins, $\mathrm{N}$ source $\times$ substrate interactions $(\mathrm{p}=0.065$ to 0.002 ) were detected for $\mathrm{CH}_{4}$ production and $\mathrm{CH}_{4}$ /total VFA ratio. The increases in $\mathrm{CH}_{4}$ production observed by replacing the NPN with protein-N were higher $(\mathrm{p}<0.05)$ for STAR than for CEL substrate, but the opposite was observed for the increases in volatile fatty acid (VFA) production. As a consequence, replacing the NPN by increased levels of CA or SP led to linear increases $(\mathrm{p}<0.05)$ in $\mathrm{CH}_{4} /$ total VFA ratio with STAR, whereas $\mathrm{CH}_{4} /$ total VFA ratio tended $(\mathrm{p}<0.10)$ to be decreased with CEL substrate. Increasing the amount of both proteins decreased linearly $(\mathrm{p}<0.05)$ ammonia- $\mathrm{N}$ concentrations, which may indicate an incorporation of amino acids and peptides into microbial protein without being first deaminated into ammonia-N. In incubations with the tested $\mathrm{N}$ sources as the only substrate, the fermentation of $1 \mathrm{mg}$ of CA or SP produced 1.24 and $0.60 \mu \mathrm{mol}$ of $\mathrm{CH}_{4}$ respectively. The results indicate the generation of $\mathrm{CH}_{4}$ from protein fermentation, and that the response of $\mathrm{CH}_{4}$ production to protein-N supply may differ with the basal substrate.

\section{Introduction}

Reducing methane $\left(\mathrm{CH}_{4}\right)$ emissions without negatively affecting animals' productivity is currently an important goal of ruminants' nutritionists, as $\mathrm{CH}_{4}$ represents a significant loss of energy for the host animal and contributes to global warming (Moss et al., 2000). Several factors have been shown to influence enteric production of $\mathrm{CH}_{4}$, but dietary characteristics are recognized as one of the most important (Kumar et al., 2014). Many studies have investigated the influence of the amount and type of carbohydrate in the diet, and it is well known that the fermentation of diets rich in structural carbohydrates yields higher $\mathrm{CH}_{4}$ emissions compared with that of diets high in soluble carbohydrates (Johnson and Johnson, 1995). In contrast, to our knowledge no work has been conducted to specifically assess the contribution of protein fermentation to ruminal $\mathrm{CH}_{4}$ production, although protein degradation in vitro has been shown to generate lower amounts of gas than carbohydrates' degradation (Cone and Van Gelder, 1999; Jentsch et al., 2007). The process of degradation of dietary protein and assimilation into microbial protein can result in either a net consumption or a net production of hydrogen, as the protein synthesis utilizes reducing equivalents and the synthesis of amino acids can result in either production or utilization of reducing equivalents (Knapp et al., 2014), but there is a lack of information on how these processes may affect $\mathrm{CH}_{4}$ production.

Several studies have shown that providing protein$\mathrm{N}$ in addition to $\mathrm{NH}_{3}-\mathrm{N}$ stimulated the growth of rumen bacteria and enhanced fibre digestion (Griswold et al., 1996; Molina-Alcaide et al., 1996), but to our knowledge no study has specifically addressed the 
influence of the substrate characteristics on the response to protein-N sources. Some authors (Cruz Soto et al., 1994) have hypothesized that the degree of stimulation by protein- $\mathrm{N}$ is related to carbohydrate fermentation rate, with greater responses occurring with more rapidly fermented substrates, but others have reported a marked stimulation of microbial growth with fibrous slowly fermented substrates (Carro and Miller, 1999; Ranilla et al., 2001). To our knowledge, no study has specifically addressed the influence of the substrate characteristics (carbohydrate and $\mathrm{N}$ sources) on $\mathrm{CH}_{4}$ production. Our hypothesis was that the contribution of protein fermentation to $\mathrm{CH}_{4}$ emission might vary with the type of carbohydrate available to ruminal microbes. The objective of this experiment was therefore to investigate the influence of the $\mathrm{N}$ source on in vitro $\mathrm{CH}_{4}$ production from the fermentation of two pure substrates composed by carbohydrates of variable fermentation rate.

\section{Materials and methods}

Animals and feeding

Four adult rumen-fistulated sheep $(65.2 \pm 2.15 \mathrm{~kg}$ body weight) were used as rumen fluid donors for the in vitro incubations. Animals were placed in individual pens with free access to water and a mineral-vitamin mixture. Sheep were fed a 2:1 mixed diet of lucerne hay and a commercial concentrate at energy maintenance level (44 g of dry matter (DM)/kg body weight $^{0.75}$; Agricultural Research Council, 1984) distributed in two equal meals. The diet contained 913, 168,426 and $269 \mathrm{~g}$ of organic matter, crude protein, neutral detergent fibre (NDF) and acid detergent fibre (ADF) per kg of dry matter respectively. Animals' management and rumen content withdrawal were carried out in accordance with the Spanish guidelines for experimental animal protection (Royal Decree 53/ 2013 of February lst on the protection of animals used for experimentation or other scientific purposes) in line with the European Directive for the Protection of animals used for scientific purposes (Directive 2010/ $63 / \mathrm{UE})$. All the experimental procedures were approved by the Institutional Animal Care and Use Committee of the Polytechnic University of Madrid.

\section{Substrates, $\mathrm{N}$ sources and in vitro incubations}

Two N-free substrates were prepared by mixing (DM basis) maize starch (Cerestar 3406, Manuel Riesgo S.A., Madrid, Spain) and cellulose (sodium carboxymethylcellulose, Manuel Riesgo S.A.) in proportions of 75:25 and 25:75 (STAR and CEL substrates respectively). Samples (160 mg of DM) of each substrate were weighed into $120-\mathrm{ml}$ serum bottles. Three forms of added $\mathrm{N}$ were evaluated: ammonia-N (NPN; $\mathrm{NH}_{4} \mathrm{Cl}$ ), casein (CA; Manuel Riesgo S.A.) and purified soya bean protein (SP; SUPRO ${ }^{\circledR} 500 E$, Protein Technologies International, Corby, Northants, UK). Casein was chosen for its rapid degradation rate by ruminal microbes and SP for being more slowly degraded (Eschenlauer et al., 2002; Broderick et al., 2004). The lower degradation rate of SP was tested in the laboratory before conducting the experiment by incubating CA and SP as only substrates as described below. Values of gas production from SP fermentation were $0.80,0.81,0.84,0.88,0.90$ and 0.96 of those for CA at $2,4,6,9,12$ and $16.5 \mathrm{~h}$ of incubation, respectively (mean values for each treatment not shown).

Five treatments were made by replacing NPN with either CA or SP at levels of 0 (NPN), 50 (CA50 and SP50) and $100 \%$ (CA100 and SP100) of total N. Isonitrogenous solutions of each treatment were prepared in buffer $(\mathrm{pH}=8.4)$ and $2 \mathrm{ml}$ of the corresponding solution (containing $5.6 \mathrm{mg} \mathrm{N}$ ) was added to each bottle immediately before sealing. All $\mathrm{N}$ treatments were applied at a level of $35 \mathrm{mg}$ of N/g of substrate organic matter $(\mathrm{OM})$, which is above the mean value of $32 \mathrm{mg}$ of N/g OM apparently fermented in the rumen recommended by the Agricultural Research Council (1984) for optimal microbial growth. For the calculations of the amount of $\mathrm{N}$ to be added to each culture, it was assumed that all $\mathrm{N}$ sources and both substrates had a potential degradability of $100 \%$.

Rumen content from each donor sheep was obtained immediately before the afternoon feeding, strained through four layers of cheesecloth and mixed with a buffer solution in a 1:4 ratio (vol/vol) at $39{ }^{\circ} \mathrm{C}$ under continuous flushing with $\mathrm{CO}_{2}$. The medium of Goering and Van Soest (1970) was modified by replacing the $\left(\mathrm{NH}_{4}\right) \mathrm{HCO}_{3}$ with $\mathrm{NaHCO}_{3}$ and excluding the trypticase, and the resulting $\mathrm{N}$-free solution was used as buffer. A solution of isobutyrate, isovalerate and valerate acids was added to each mixture of rumen fluid plus buffer to achieve final concentrations of 0.3 , 0.9 and $0.7 \mathrm{~mm}$, respectively, in order to stimulate the growth of cellulolytic bacteria (Hume, 1970).

Bottles were sealed with rubber stoppers and aluminium caps, incubated at $39^{\circ} \mathrm{C}$ and withdrawn $16.5 \mathrm{~h}$ after inoculation (corresponding to a mean passage rate from the rumen of 0.06 per hour). Total gas production was measured using a pressure transducer (HD2304.0 pressure gauge, DELTA OHM, Padova, Italy) and a calibrated syringe. A gas sample $(10 \mathrm{ml})$ was removed from each bottle and stored in a vacuum tube (Terumo Europe N.V., Leuven, 
Belgium) for analysis of $\mathrm{CH}_{4}$. Bottles were then uncapped, and the $\mathrm{pH}$ was measured immediately with a pH meter (Crison Basic 20; Crisson Instruments, Barcelona, Spain). Three millilitres of content was added to $3 \mathrm{ml}$ of deproteinising solution (20 $\mathrm{g}$ of metaphosphoric acid and $0.6 \mathrm{~g}$ of crotonic acid per $\mathrm{l}$ ) for volatile fatty acid (VFA) determination and $2 \mathrm{ml}$ was added to $2 \mathrm{ml} 0.5 \mathrm{M} \mathrm{HCl}$ for $\mathrm{NH}_{3}-\mathrm{N}$ analysis.

Incubations were performed in four different days, and each day, the rumen fluid from one sheep was used as inoculum. A total of 32 bottles were incubated each day: 20 bottles with substrate and N sources (two for each substrate and $\mathrm{N}$ treatment), 10 bottles only with $\mathrm{N}$ sources (two per $\mathrm{N}$ treatment) and two additional bottles with only buffered ruminal fluid from sheep (blanks).

\section{Chemical analyses}

Dry matter (ID 934.01), ash (ID 942.05) and N (ID 984.13) contents of the diet fed to donor sheep were determined according to the Association of Official Analytical Chemists (1999). The NDF and ADF analyses were carried out according to Van Soest et al. (1991) using an ANKOM220 Fiber Analyzer unit (ANKOM Technology Corporation, Fairport, NY, USA). Sodium sulphite and heat-stable amylase were used in the sequential analysis of NDF and ADF, and they were expressed exclusive of residual ash.

Concentrations of $\mathrm{NH}_{3}-\mathrm{N}$ in ruminal fluid were determined using a spectrophotometer by the method of phenol-hypochlorite (Weatherburn, 1967) and those of VFA by gas chromatography as described by Carro et al. (1992). Analysis of $\mathrm{CH}_{4}$ was carried out following the procedure of Martínez et al. (2010) using a gas chromatograph (Shimadzu GC 14B; Shimadzu Europa GmbH, Duisburg, Germany) equipped with a flame ionization detector and a column packed with Carboxen 1000 (Supelco, Madrid, Spain).

\section{Calculations and statistical analyses}

The amounts of VFA produced in each culture were calculated by subtracting the amount present initially in the incubation medium from that determined at the end of the incubation period. The volume of gas produced was corrected for temperature and pressure $\left(0{ }^{\circ} \mathrm{C}\right.$ and $1 \mathrm{~atm}$, respectively) before calculating the amount of $\mathrm{CH}_{4}$ produced. The amount of organic matter apparently fermented (OMAF) in each bottle was estimated from acetate, propionate and butyrate productions as described by Demeyer (1991). No correction for the values measured in the blanks was made for calculations of VFA and $\mathrm{CH}_{4}$ productions. Values determined in the two bottles incubated for each inoculum and experimental treatment were averaged before statistical analysis (four values per experimental treatment). Values in the two bottles were similar, with CV lower than $2.0 \%$.

Data for each protein source (CA and SP) were analysed independently as a mixed model using the PROC MIXED of SAS (SAS, 2012). In the cultures with substrate (STAR and CEL), the effects of $N$ source $(0,50$ and $100 \%$ protein-N), substrate and $N$ source $\times$ substrate were considered fixed, and inoculum effect was considered random. In the cultures with only the $\mathrm{N}$ forms added (no substrate), the effect of $\mathrm{N}$ source $(0$, 50 and $100 \%$ protein-N) was considered fixed, and inoculum effect was considered random. As the substitution of NNP by protein-N was made at equally spaced intervals $(0,50$ and $100 \%)$, orthogonal polynomial contrasts were used to test for linear and quadratic effects of protein-N addition. Significance was declared at $p<0.05$, whereas $p<0.10$ values were considered to be a trend.

\section{Results}

The effects of replacing NPN by CA and SP are shown in Tables 1 and 2 respectively. There were no $\mathrm{N}$ source $\times$ substrate interactions $(p=0.114$ to 0.937$)$ for any measured variable with the exception of $\mathrm{CH}_{4}$ / total VFA ratio for both proteins $(\mathrm{p}=0.011$ and 0.009 for CA and SP, respectively), $\mathrm{CH}_{4}$ production for SP $(p=0.002)$ and propionate production $(p=0.046)$ for CA. When these parameters were analysed independently for each substrate, the replacement of NPN by increased levels of CA or SP led to linear increases ( $p=0.023$ and 0.003 , respectively) of $\mathrm{CH}_{4} /$ total VFA ratio with STAR, but the $\mathrm{CH}_{4} /$ total VFA ratio tended to be decreased with CEL $(p=0.053$ and 0.056 for CA and SP respectively). Production of $\mathrm{CH}_{4}$ was linearly increased $(p<0.001)$ when SP was supplied to STAR substrate, and quadratically increased $(p=0.002)$ with CEL substrate. Replacing NPN by increased levels of CA increased propionate production with CEL (quadratic, $\mathrm{p}=0.044$ ), but had no effect with STAR $(p=0.165)$. In addition, a trend to $\mathrm{N}$ source $\times$ substrate interaction was observed for $\mathrm{CH}_{4}$ production with CA $(p=0.065)$ and for propionate production with SP $(p=0.066)$.

Final pH values ranged from 6.56 to 6.89 (values not shown) and were not affected $(\mathrm{p}>0.05)$ by $\mathrm{N}$ treatments, possibly due to the high buffer capacity of the incubation medium. Replacing NPN by increasing amounts of CA augmented the amount of both gas 
Table 1 Effects of replacing non-protein nitrogen (NPN) by casein on the in vitro fermentation of substrates composed by starch and cellulose in ratios 75:25 (STAR) or 25:75 (CEL) incubated in batch cultures of mixed ruminal micro-organisms for $16.5 \mathrm{~h}^{*}$

\begin{tabular}{|c|c|c|c|c|c|c|c|c|c|c|c|}
\hline \multirow[b]{3}{*}{ Item } & \multirow{2}{*}{\multicolumn{3}{|c|}{ STAR }} & \multirow{2}{*}{\multicolumn{4}{|c|}{ CEL }} & \multicolumn{4}{|l|}{$p$ value } \\
\hline & & & & & & & & \multicolumn{2}{|c|}{$\begin{array}{l}\text { Nitrogen } \\
\text { source } \dagger\end{array}$} & \multirow[b]{2}{*}{ Substrate } & \multirow{2}{*}{$\begin{array}{l}\text { Nitrogen } \\
\text { source } \times \\
\text { substrate }\end{array}$} \\
\hline & NPN & CA50 & CA100 & NPN & CA50 & CA100 & SEM & $\mathrm{L}$ & C & & \\
\hline Gas ( $\mu$ mol) & 2076 & 1991 & 2195 & 931 & 1102 & 1115 & 58.3 & 0.473 & 0.021 & $<0.001$ & 0.114 \\
\hline $\mathrm{CH}_{4}(\mu \mathrm{mol})$ & 259 & 358 & 400 & 195 & 245 & 270 & 13.4 & $<0.001$ & $<0.001$ & $<0.001$ & 0.065 \\
\hline \multicolumn{12}{|c|}{ Volatile fatty acid ( $\mu \mathrm{mol})$} \\
\hline Total & 863 & 955 & 1021 & 313 & 463 & 595 & 30.5 & 0.001 & $<0.001$ & $<0.001$ & 0.166 \\
\hline Acetate & 472 & 567 & 609 & 179 & 278 & 355 & 20.8 & $<0.001$ & $<0.001$ & $<0.001$ & 0.598 \\
\hline Propionate & 199 & 173 & 172 & 66.0 & 76.0 & 97.3 & 10.52 & 0.478 & 0.499 & $<0.001$ & 0.046 \\
\hline Butyrate & 167 & 172 & 173 & 55.0 & 75.5 & 87.2 & 9.41 & 0.205 & 0.141 & $<0.001$ & 0.398 \\
\hline Isobutyrate & 5.38 & 8.65 & 12.9 & 2.83 & 6.13 & 11.0 & 0.959 & 0.004 & $<0.001$ & 0.010 & 0.925 \\
\hline Isovalerate & 7.08 & 15.6 & 24.5 & 7.20 & 15.1 & 24.8 & 1.321 & $<0.001$ & $<0.001$ & 0.999 & 0.948 \\
\hline Valerate & 12.6 & 18.4 & 30.6 & 2.64 & 12.2 & 19.5 & 2.366 & 0.005 & $<0.001$ & $<0.001$ & 0.566 \\
\hline $\begin{array}{l}\text { Acetate/Propionate } \\
(\mathrm{mol} / \mathrm{mol})\end{array}$ & 2.40 & 3.29 & 3.61 & 2.99 & 3.70 & 3.64 & 0.278 & 0.011 & 0.043 & 0.150 & 0.597 \\
\hline $\mathrm{CH}_{4} / \mathrm{VFA}(\mathrm{mol} / \mathrm{mol})$ & 0.300 & 0.375 & 0.391 & 0.623 & 0.529 & 0.454 & 0.0418 & 0.560 & 0.384 & $<0.001$ & 0.011 \\
\hline $\begin{array}{l}\text { Organic matter } \\
\text { apparently } \\
\text { fermented (mg) }\end{array}$ & 82.4 & 87.8 & 91.3 & 29.6 & 41.4 & 50.3 & 3.08 & 0.014 & 0.001 & $<0.001$ & 0.194 \\
\hline $\mathrm{NH}_{3}-\mathrm{N}(\mathrm{mg} / \mathrm{l})$ & 295 & 252 & 246 & 285 & 253 & 247 & 13.7 & 0.015 & 0.053 & 0.815 & 0.907 \\
\hline
\end{tabular}

*NPN, CA50 and CA100: treatments whereby ammonia- $\mathrm{N}\left(\mathrm{NPN} ; \mathrm{NH}_{4} \mathrm{Cl}\right.$ ) was replaced by casein- $\mathrm{N}$ at levels 0,50 and $100 \%$ of total $\mathrm{N}$ respectively.

$\dagger$ Linear (L) and quadratic (C) effects of casein.

Table 2 Effects of replacing non-protein nitrogen (NPN) by purified soya bean protein on the in vitro fermentation of substrates composed by starch and cellulose in ratios 75:25 (STAR) or 25:75 (CEL) incubated in batch cultures of mixed ruminal micro-organisms for $16.5 \mathrm{~h}$ *

\begin{tabular}{|c|c|c|c|c|c|c|c|c|c|c|c|}
\hline \multirow[b]{3}{*}{ Item } & \multirow{2}{*}{\multicolumn{3}{|c|}{ STAR }} & \multirow{2}{*}{\multicolumn{4}{|c|}{ CEL }} & \multicolumn{4}{|l|}{$p$ value } \\
\hline & & & & & & & & \multicolumn{2}{|l|}{$\begin{array}{l}\text { Nitrogen } \\
\text { source† }\end{array}$} & \multirow[b]{2}{*}{ Substrate } & \multirow{2}{*}{$\begin{array}{l}\text { Nitrogen } \\
\text { source } \times \\
\text { substrate }\end{array}$} \\
\hline & NPN & SP50 & SP100 & NPN & SP50 & SP100 & SEM & L & C & & \\
\hline Gas ( $\mu$ mol) & 2076 & 1903 & 2063 & 931 & 937 & 1138 & 59.1 & 0.176 & 0.016 & $<0.001$ & 0.173 \\
\hline $\mathrm{CH}_{4}(\mu \mathrm{mol})$ & 259 & 391 & 390 & 195 & 210 & 253 & 13.4 & $<0.001$ & $<0.001$ & $<0.001$ & 0.002 \\
\hline \multicolumn{12}{|c|}{ Volatile fatty acid ( $\mu \mathrm{mol})$} \\
\hline Total & 863 & 923 & 959 & 313 & 411 & 497 & 23.8 & 0.005 & $<0.001$ & $<0.001$ & 0.210 \\
\hline Acetate & 472 & 576 & 590 & 179 & 244 & 307 & 14.2 & $<0.001$ & $<0.001$ & $<0.001$ & 0.224 \\
\hline Propionate & 199 & 145 & 156 & 66.0 & 65.7 & 73.5 & 13.08 & 0.089 & 0.825 & $<0.001$ & 0.066 \\
\hline Butyrate & 167 & 169 & 175 & 55.0 & 82.0 & 86.7 & 6.50 & 0.091 & 0.066 & $<0.001$ & 0.261 \\
\hline Isobutyrate & 5.38 & 7.54 & 8.80 & 2.83 & 4.30 & 7.00 & 0.850 & 0.051 & 0.001 & 0.003 & 0.707 \\
\hline Isovalerate & 7.08 & 11.4 & 13.9 & 7.20 & 9.65 & 15.9 & 0.923 & 0.002 & $<0.001$ & 0.872 & 0.162 \\
\hline Valerate & 12.6 & 13.2 & 15.6 & 2.64 & 4.57 & 7.52 & 1.539 & 0.572 & 0.033 & $<0.001$ & 0.937 \\
\hline $\begin{array}{l}\text { Acetate/Propionate } \\
(\mathrm{mol} / \mathrm{mol})\end{array}$ & 2.40 & 3.97 & 4.01 & 2.99 & 3.85 & 4.19 & 0.527 & 0.070 & 0.228 & 0.437 & 0.323 \\
\hline $\mathrm{CH}_{4} / \mathrm{VFA}(\mathrm{mol} / \mathrm{mol})$ & 0.300 & 0.424 & 0.407 & 0.623 & 0.511 & 0.509 & 0.0424 & 0.931 & 0.855 & $<0.001$ & 0.009 \\
\hline $\begin{array}{l}\text { Organic matter } \\
\text { apparently } \\
\text { fermented (mg) }\end{array}$ & 82.4 & 85.8 & 87.0 & 29.6 & 37.6 & 45.0 & 2.26 & 0.024 & 0.002 & $<0.001$ & 0.089 \\
\hline $\mathrm{NH}_{3}-\mathrm{N}(\mathrm{mg} / \mathrm{l})$ & 295 & 232 & 175 & 285 & 223 & 187 & 13.8 & $<0.001$ & $<0.001$ & 0.847 & 0.699 \\
\hline
\end{tabular}

*NPN, SP50 and SP100: treatments whereby ammonia-N (NPN; $\mathrm{NH}_{4} \mathrm{Cl}$ ) was replaced by soya bean- $\mathrm{N}$ at levels 0, 50 and 100\% of total $\mathrm{N}$ respectively. $\dagger$ Linear (L) and quadratic (C) effects of soya bean protein. 
(quadratic, $\mathrm{p}=0.021$ ) and $\mathrm{CH}_{4}$ (linear and quadratic, $\mathrm{p}<0.001)$. Similarly, total VFA production and OMAF were linearly $(p=0.001$ and 0.014 , respectively) and quadratically $(p<0.001$ for both) increased with increasing CA supplementation. There were no effects $(p>0.05)$ of CA supply on propionate and butyrate productions, but acetate, isobutyrate, isovalerate and valerate productions were increased (quadratic, $\mathrm{p}<0.001$ ) and $\mathrm{NH}_{3}-\mathrm{N}$ concentrations decreased (linear, $p=0.015$ ) by supplying increased amounts of CA.

Substituting of NPN by SP also increased both gas (quadratic, $\mathrm{p}=0.016$ ) and $\mathrm{CH}_{4}$ (linear and quadratic, $\mathrm{p}<0.001)$ productions, as well as total VFA production (linear, $\mathrm{p}<0.05$; quadratic, $\mathrm{p}<0.001$ ) and OMAF (linear, $\mathrm{p}=0.024$; quadratic, $\mathrm{p}=0.002$ ). Quadratic increases $(\mathrm{p}<0.001$ to 0.033$)$ in the production of acetate, isobutyrate, isovalerate and valerate, and a trend to increased butyrate production $(p=0.066)$ were observed by adding SP to the cultures. Concentrations of $\mathrm{NH}_{3}-\mathrm{N}$ were linearly and quadratically decreased $(\mathrm{p}<0.001)$ by replacing NPN with increased amounts of SP.

As expected, there were marked differences in fermentation parameters between the two substrates. With all $\mathrm{N}$ sources, STAR fermentation resulted in higher $(\mathrm{p}<0.001)$ OMAF and production of gas, $\mathrm{CH}_{4}$ and total VFA, but lower $\mathrm{CH}_{4} /$ total VFA ratios compared with fermentation of CEL. The amounts of all individual VFA produced, except those of isovalerate, were higher $(p<0.010)$ with STAR than with CEL. In contrast, no differences $(\mathrm{p}>0.05)$ between substrates were observed in the acetate/propionate ratio.

The effects of replacing NPN by CA and SP in the batch cultures in the absence of substrate are shown in Tables 3 and 4 respectively. Adding both protein-N sources to the cultures resulted in increased $\mathrm{CH}_{4}$ (linear, $\mathrm{p}=0.008$ and 0.019 for CA and SP, respectively; quadratic, $\mathrm{p} \leq 0.001$ for both proteins) and total VFA production (linear, $\mathrm{p}=0.008$ and $<0.001$ for CA and $\mathrm{SP}$, respectively; quadratic, $\mathrm{p}<0.001$ for both). The amount of all individual VFA was quadratically increased compared with NPN treatment for both CA $(\mathrm{p}<0.001$ to 0.006$)$ and SP $(\mathrm{p}<0.001$ to 0.045$)$, whereas acetate/propionate ratio was quadratically decreased $(\mathrm{p}=0.021$ and 0.047 for CA and SP, respectively). The amount of OMAF was increased (linear, $\mathrm{p}=0.027$ and 0.016 for $\mathrm{CA}$ and SP, respectively; quadratic, $\mathrm{p}=0.002$ and 0.014 ), whereas $\mathrm{NH}_{3}-\mathrm{N}$ concentrations were reduced by supplementing both protein- $\mathrm{N}$ sources (quadratic for $\mathrm{CA}, \mathrm{p}=0.035$; linear, $\mathrm{p}=0.002$, and quadratic, $\mathrm{p}<0.001$ for SP).

\section{Discussion}

Two synthetic substrates with different rate of degradation were used to analyse the possible interaction between the type of substrate and the $\mathrm{N}$ source on $\mathrm{CH}_{4}$ production and substrate fermentation. Because all $\mathrm{N}$ treatments were applied at a rate considered adequate for optimal microbial growth (Agricultural Research Council, 1984) and minor VFA required for
Table 3 Effects of replacing non-protein nitrogen (NPN) by casein on in vitro fermentations in the absence of substrate in batch cultures of mixed ruminal micro-organisms incubated for $16.5 \mathrm{~h}$

\begin{tabular}{|c|c|c|c|c|c|c|}
\hline \multirow[b]{2}{*}{ Item } & \multicolumn{3}{|c|}{ Treatment* } & \multirow[b]{2}{*}{ SEM } & \multicolumn{2}{|c|}{$p$ value $\dagger$} \\
\hline & BNPN & BCA50 & BCA100 & & L & C \\
\hline Gas ( $\mu \mathrm{mol})$ & 342 & 387 & 546 & 33.5 & 0.377 & 0.005 \\
\hline $\mathrm{CH}_{4}(\mu \mathrm{mol})$ & 90.3 & 116.6 & 140.2 & 4.76 & 0.008 & 0.001 \\
\hline \multicolumn{7}{|l|}{ Volatile fatty acid ( $\mu \mathrm{mol}$ ) } \\
\hline Total & 100 & 226 & 342 & 22.6 & 0.008 & $<0.001$ \\
\hline Acetate & 70.0 & 129 & 182 & 13.0 & 0.018 & 0.002 \\
\hline Propionate & 8.5 & 30.0 & 54.8 & 3.61 & 0.006 & $<0.001$ \\
\hline Butyrate & 6.20 & 16.1 & 35.0 & 4.11 & 0.139 & 0.003 \\
\hline Isobutyrate & 2.99 & 11.6 & 17.0 & 0.743 & $<0.001$ & $<0.001$ \\
\hline Isovalerate & 10.6 & 26.4 & 36.6 & 1.13 & $<0.001$ & $<0.001$ \\
\hline Valerate & 1.83 & 12.2 & 17.1 & 2.001 & 0.010 & 0.006 \\
\hline $\begin{array}{l}\text { Acetate/Propionate } \\
(\mathrm{mol} / \mathrm{mol})\end{array}$ & 9.39 & 4.29 & 3.30 & 0.930 & 0.008 & 0.021 \\
\hline $\mathrm{CH}_{4} / \mathrm{VFA}(\mathrm{mol} / \mathrm{mol})$ & 0.930 & 0.516 & 0.410 & 0.1173 & 0.012 & 0.044 \\
\hline $\begin{array}{l}\text { Organic matter } \\
\text { apparently fermented (mg) }\end{array}$ & 7.14 & 15.5 & 24.8 & 2.03 & 0.027 & 0.002 \\
\hline $\mathrm{NH}_{3}-\mathrm{N}(\mathrm{mg} / \mathrm{l})$ & 331 & 332 & 268 & 19.1 & 0.972 & 0.035 \\
\hline
\end{tabular}

*BNPN, BCA50 and BCA100: treatments whereby ammonia-N (BNPN; $\left.\mathrm{NH}_{4} \mathrm{Cl}\right)$ was replaced by casein- $\mathrm{N}$ at levels 0,50 and $100 \%$ of total $\mathrm{N}$ respectively.

$\dagger$ Linear (L) and quadratic (C) effects of casein. 


\begin{tabular}{|c|c|c|c|c|c|c|}
\hline \multirow[b]{2}{*}{ Item } & \multicolumn{3}{|c|}{ Treatment* } & \multirow[b]{2}{*}{ SEM } & \multicolumn{2}{|l|}{$p$ value $\dagger$} \\
\hline & BNPN & BSP50 & BSP100 & & $\mathrm{L}$ & $\mathrm{C}$ \\
\hline Gas ( $\mu \mathrm{mol})$ & 342 & 333 & 340 & 16.6 & 0.714 & 0.906 \\
\hline $\mathrm{CH}_{4}(\mu \mathrm{mol})$ & 90.3 & 101.8 & 116.6 & 2.53 & 0.019 & $<0.001$ \\
\hline \multicolumn{7}{|l|}{ Volatile fatty acid ( $\mu \mathrm{mol})$} \\
\hline Total & 100 & 146 & 198 & 5.0 & $<0.001$ & $<0.001$ \\
\hline Acetate & 70.0 & 96.9 & 123 & 4.42 & 0.005 & $<0.001$ \\
\hline Propionate & 8.5 & 15.3 & 27.9 & 1.73 & 0.031 & $<0.001$ \\
\hline Butyrate & 6.20 & 8.95 & 11.17 & 0.534 & 0.008 & $<0.001$ \\
\hline Isobutyrate & 2.99 & 5.95 & 8.65 & 1.160 & 0.144 & 0.045 \\
\hline Isovalerate & 10.6 & 15.8 & 20.0 & 0.737 & 0.003 & $<0.001$ \\
\hline Valerate & 1.83 & 3.43 & 7.52 & 0.606 & 0.057 & $<0.001$ \\
\hline Acetate/Propionate (mol/mol) & 9.39 & 6.25 & 4.61 & 1.050 & 0.079 & 0.047 \\
\hline $\mathrm{CH}_{4} / \mathrm{VFA}(\mathrm{mol} / \mathrm{mol})$ & 0.930 & 0.697 & 0.589 & 0.0937 & 0.029 & 0.108 \\
\hline $\begin{array}{l}\text { Organic matter } \\
\text { apparently fermented (mg) }\end{array}$ & 7.14 & 11.5 & 13.2 & 0.92 & 0.016 & 0.014 \\
\hline $\mathrm{NH}_{3}-\mathrm{N}(\mathrm{mg} / \mathrm{l})$ & 331 & 283 & 182 & 6.6 & 0.002 & $<0.001$ \\
\hline
\end{tabular}

Table 4 Effects of replacing non-protein nitrogen (NPN) by purified soya bean protein on the in vitro fermentations in the absence of substrate in batch cultures of mixed ruminal micro-organisms incubated for $16.5 \mathrm{~h}$

*BNPN, BSP50 and BSP100: treatments whereby ammonia- $\mathrm{N}\left(\mathrm{BNPN} ; \mathrm{NH}_{4} \mathrm{Cl}\right)$ was replaced by soya bean- $\mathrm{N}$ at levels 0,50 and $100 \%$ of total $\mathrm{N}$ respectively.

† Linear effect $(\mathrm{L})$ and quadratic $(\mathrm{C})$ of soya bean protein.

the growth of cellulolytic bacteria was added to the incubation medium, it was assumed that there were no limitations for the growth of ruminal bacteria. The $\mathrm{NH}_{3}-\mathrm{N}$ concentrations in the incubation medium (mixture of buffer plus ruminal fluid) were similar in each of the incubation days $(39.3,37.5,34.3$ and $36.7 \mathrm{mg} \mathrm{NH}$ - $\mathrm{N} / \mathrm{l}$ for sheep 1, 2, 3 and 4 respectively). In addition, $\mathrm{N}: \mathrm{S}$ ratio was lower than 10:1 in all $\mathrm{N}$ treatments, thus preventing a limitation of $S$ for the synthesis of S-containing amino acids by ruminal microbes (Ørskov, 1982).

The increases in $\mathrm{CH}_{4}$ production observed by replacing the NPN by protein-N were higher for STAR (120 and $132 \mu \mathrm{mol} /$ culture for $\mathrm{CA}$ and SP, respectively; values averaged across substitution levels) than for CEL substrate (63 and $37 \mu \mathrm{mol} /$ culture respectively). In contrast, the increases in VFA production were lower for STAR (125 and $78 \mu \mathrm{mol} /$ culture for CA and SP, respectively; values averaged across substitution levels) compared with CEL (216 and $141 \mu \mathrm{mol}$ per culture). The differences in the response to the supply of protein-N between STAR and CEL substrates resulted in significant $\mathrm{N}$ source $\times$ substrate interactions for $\mathrm{CH}_{4} / \mathrm{VFA}$ ratio. The ratio $\mathrm{CH}_{4} / \mathrm{VFA}$ can be used as an indicator of the efficiency of ruminal fermentation, as $\mathrm{CH}_{4}$ is an energy loss to the host animal and VFA is used as an energy source and as substrates for the synthesis of other compounds. Whereas providing protein- $\mathrm{N}$ enhanced $\mathrm{CH}_{4} /$ total VFA ratio with STAR, the opposite was observed with CEL. These results might indicate that under conditions of limited energy availability, carbon skeletons resulting from amino acid deamination are mainly fermented to VFA, whereas amino acids can be used for microbial protein synthesis at a higher degree when energy is available. Differences between substrates in the availability of methyl groups due to variable protein degradation and amino acid composition may have also contributed to the observed differences in $\mathrm{CH}_{4}$ production, as methanogens of the order Thermoplasmatales that use methyl groups rather than $\mathrm{H}_{2}$ have been identified in the rumen (Kim et al., 2011; Poulsen et al., 2013). It should be noticed that the in vitro experiments conducted in this experiment lasted for $16.5 \mathrm{~h}$, and some methanogens have greater half-lives (Hook et al., 2010); therefore, long-term in vitro studies are necessary to confirm these results.

Only few studies have compared the effects of the $\mathrm{N}$ source on $\mathrm{CH}_{4}$ production and all have been conducted with fibrous substrates. Carro and Miller (1999) observed a $10.1 \%$ increase in $\mathrm{CH}_{4}$ production by replacing half of the NPN by SP in Rusitec fermenters receiving an all-fibre diet, which is quite well in agreement with the $7.7 \%$ of increase observed in the present study for the SP50 treatment and CEL substrate. Carro et al. (1999a) reported lower increases in $\mathrm{CH}_{4}$ production $(4.3-6.9 \%)$ in batch cultures with low-quality forages by fully replacing urea by casein than the $38.5 \%$ of increase observed in the present study for the CAl00 treatment with CEL substrate. However, the substrates used in the study by Carro et al. (1999a) contained protein-N $(67-78 \mathrm{~g} / \mathrm{kg}$ of $\mathrm{DM})$ and urea or casein were added up only to reach $30 \mathrm{mg}$ of degradable N/g OM apparently fermented, 
whereas in the present study substrates and incubation medium were $\mathrm{N}$-free and all the $\mathrm{N}$ was supplied by the experimental treatments.

The results from the batch cultures with the $\mathrm{N}$ sources as the only substrate also showed that the fermentation of CA and SP leads to $\mathrm{CH}_{4}$ production, which is in agreement with studies in cattle reporting that protein supplementation of forage-based diets increased $\mathrm{CH}_{4}$ production (de Oliveira et al., 2007; Shreck et al., 2015). Blaxter and Martin (1962) measured $\mathrm{CH}_{4}$ production in sheep fed dried grass and observed that infusing daily 15-31 g of casein-N into the rumen increased $\mathrm{CH}_{4}$ emissions by $1.82 \pm 0.275 \mathrm{~mol}$ per $\mathrm{g}$ of casein infused. This value is higher than the $1.24 \pm 0.172 \mathrm{~mol}$ per $\mathrm{g}$ of added CA observed in the present study, but also revealed a great variability between individual sheep. The two sheep used in the study of Blaxter and Martin (1962) gave values of 2.12 and $1.18 \mathrm{~mol}$ of $\mathrm{CH}_{4}$ per $\mathrm{g}$ of added CA, whereas the values for the four inocula used in our study were $0.55,1.18,1.52$ and $1.72 \mathrm{~mol}$ of $\mathrm{CH}_{4}$ per $\mathrm{g}$ of $\mathrm{CA}$. The great variability in $\mathrm{CH}_{4}$ production per $\mathrm{g}$ of CA supports previous observations on the considerable variation in the amount of $\mathrm{CH}_{4}$ produced by individual sheep (Pinares-Patiño et al., 2003). The lower amounts of $\mathrm{CH}_{4}$ produced from fermentation of SP $\left(0.35,0.58,0.60\right.$ and $0.89 \mathrm{~mol}^{\circ} \mathrm{CH}_{4}$ per $g$ of SP for the four inocula used in the study) compared with those for CA might be due to an incomplete fermentation of SP or to a greater incorporation of SP amino acids into microbial protein. The lower values of gas, $\mathrm{CH}_{4}$ and VFA production, as well as the lower $\mathrm{NH}_{3}-\mathrm{N}$ concentrations, observed for SP compared with CA support the hypothesis of a lower fermentation of SP after $16.5 \mathrm{~h}$ of incubation. Griswold and Mackie (1997) also reported lower ammonia-N concentrations at different incubation times (from 0 to $12 \mathrm{~h}$ ) when Prevotella ruminicola, the most numerous proteolytic bacterium in the rumen, was grown in batch cultures with SP compared with CA as the only source of N. In our study, ammonia-N concentrations were only measured at the end of the incubation, but were well above the concentration limiting in vitro microbial growth (Satter and Slyter, 1974) in all treatments.

The progressive replacement of NPN by protein-N also led to a progressive reduction in the acetate/propionate ratio from abnormally high values (9.39) in bottles with only NPN to usual values in bottles with only protein-N (3.30 and 4.61 for CA and SP respectively). The shift of this ratio by increasing the supply of protein-N may indicate a predominance of acetateproducing microbes in conditions of limited availability of substrate (just endogenous substrate added with the inoculum in NPN-bottles), as well as a proliferation of propionate-producing microbes when protein was available.

The higher increases in VFA production by supplying protein- $\mathrm{N}$ observed for CEL may indicate a more marked positive effect of protein-N on ruminal fermentation in situations of limited energy for microbial growth than in those with a rapidly available energy source (STAR substrate). Other in vivo (Wang et al., 2013) and in vitro experiments with fermenters (Merry et al., 1990; Molina-Alcaide et al., 1996; Carro and Miller, 1999) or batch cultures (Carro et al., 1999a,b; Ranilla et al., 2001) and fibrous diets have also showed that the replacement of NPN by amino acids, peptides or protein-N resulted in increased VFA production. Altogether, these results indicate a stimulating effect produced by protein- $\mathrm{N}$ on the fermentation, presumably due to changes in bacterial populations affected by the form of $\mathrm{N}$ or to changes in its activity. Wang et al. (2013) observed that the ruminal infusion of soya bean small peptides to cattle significantly increased the relative DNA abundance of Butyrivibrio fibrisolvens and decreased that of Streptococcus bovis, thus confirming changes in bacterial populations. In addition, the supply of fermentable OM in the form of protein- $\mathrm{N}$ could also have contributed to the observed increase in VFA production, as the amino acids resulting from proteolysis can be deaminated and the generated carbon skeletons be fermented to VFA (Ørskov, 1982). This fact is also shown by the increased VFA production with the progressive substitution of NPN by protein-N observed in the cultures with the $\mathrm{N}$ sources as the only substrate. The increased production of isobutyrate, isovalerate and valerate observed for both substrates by supplying CA and SP was expected, as these three VFA are major end products of amino acid fermentation (Wallace and Cotta, 1988). The decrease in $\mathrm{NH}_{3}-\mathrm{N}$ concentrations by supplying protein- $\mathrm{N}$ is difficult to interpret, as concentrations of $\mathrm{NH}_{3}-\mathrm{N}$ are the result of protein degradation and microbial protein synthesis processes. An increase in microbial protein synthesis has been observed in vivo and in vitro by replacing NPN by protein-N (Chikunya et al., 1996; Carro and Miller, 1999; Ranilla et al., 2001), and this may have contributed to the lower concentrations of $\mathrm{NH}_{3}-\mathrm{N}$ observed in the cultures receiving protein-N.

The amount of $\mathrm{CH}_{4}$ produced is positively related to the amount of OM fermented (Johnson and Johnson, 1995), and the higher amount of OM fermented for STAR compared with CEL is in accordance with the higher amount of $\mathrm{CH}_{4}$ generated in STAR 
fermentation. The lower values of total and individual VFA production observed for CEL compared with STAR agree well with the expected lower fermentability of CEL substrate. However, the lack of differences between substrates in the acetate/propionate ratio contrasts with the usual decrease in acetate/propionate ratio observed by increasing the amount of starch in the diet (Carro et al., 2000). The high buffer capacity of the culture medium can partly explain this result, as final pH values were adequate in all cultures for an optimal activity of the cellulolytic flora (Stewart, 1977). Besides, the same inoculum was used for both substrates although it has been shown that the type of diet fed to donors is an important factor influencing the in vitro fermentation parameters (Martínez et al., 2010; Mateos et al., 2013). The donor sheep were fed just one diet to avoid any additional factor of variability in the comparison of experimental treatments. Moreover, the in vitro system used in this study has a fixed substrate retention time $(16.5 \mathrm{~h}$ in our experiment), whereas retention time in the rumen is affected by feed characteristics.

In conclusion, the results indicate that the progressive replacement of NPN by protein-N increased both $\mathrm{CH}_{4}$ and VFA productions in vitro, but the magnitude of the changes was affected by the fermentability of the basal substrate. Whereas the increases in $\mathrm{CH}_{4}$ emissions were higher for the rapidly fermented substrate than for the slowly fermented one, the opposite was observed for the VFA production. These differences in the response to the supply of protein-N were attributed to differences in the use of the amino acids resulting from protein degradation and possibly to changes in the microbial populations. If these results are confirmed in vivo, avoiding an excess of degradable protein in ruminant diets would not only decrease the urinary excretion of $\mathrm{N}$, but also the $\mathrm{CH}_{4}$ emissions. In addition, the present study confirms the high individual variability in $\mathrm{CH}_{4}$ production under in vitro conditions.

\section{Acknowledgements}

Funding from the Spanish Ministry of Economy and Competitiveness (Project AGL2012-31064) and the Comunidad Autónoma de Madrid (CAM; Project MEDGAN ABI-2913) is gratefully acknowledged. J.L. Vanegas acknowledges a scholarship for PhD studies from the Ministry of Higher Education, Science, Technology and Innovation of Ecuador.
Agricultural Research Council, 1984: The Nutrient Requirements of Ruminant Livestock. Supplement no. 1. FarnhamRoyal: Commonwealth Agricultural Bureaux, Slough.

AOAC, International, 1999: Official Methods of Analysis, 16th edn, 5th rev. Association of Official Analytical Chemists International, Gaithersburg, MD.

Blaxter, K. L.; Martin, A. K., 1962: The utilization of protein as a source of energy in fattening sheep. British Journal of Nutrition 16, 397-407.

Broderick, G. A.; Udén, P.; Murphy, M. L.; Lapins, A., 2004: Sources of variation in rates of in vitro ruminal protein degradation. Journal of Dairy Science 87, 1345-1359.

Carro, M. D.; Miller, E. L., 1999: Effect of supplementing a fibre basal diet with different nitrogen forms on ruminal fermentation and microbial growth in an in vitro semicontinuous culture system (Rusitec). British Journal of Nutrition 82, 149-157.

Carro, M. D.; Lebzien, P.; Rohr, K., 1992: Influence of yeast culture on the in vitro fermentation (Rusitec) of diets containing variable portions of concentrates.
Animal Feed Science and Technology 37, 209-220.

Carro, M. D.; López, S.; Valdés, C.; González, J. S., 1999a: Effect of nitrogen form (casein and urea) on the in vitro degradation of cell walls from six forages. Journal of Animal Physiology and Animal Nutrition 81, 212-222.

Carro, M. D.; López, S.; Valdés, C.; Ranilla, M. J., 1999b: Efecto de la suplementación nitrogenada sobre la fermentación ruminal in vitro de forrajes deficientes en nitrógeno (Effect of nitrogen supplementation on in vitro rumen fermentation of nitrogen deficient forages). Archivos de Zootecnia 48, 295-306. Carro, M. D.; Valdés, C.; Ranilla, M. J.; González, J. S., 2000: Effect of forage to concentrate ratio in the diet on ruminal fermentation and digesta flow kinetics in sheep. Animal Science 70, 127-134.

Chikunya, S.; Newbold, C. J.; Rode, L. M.; Chen, X. B.; Wallace, R. J., 1996: Influence of dietary rumen-degradable protein on bacterial growth in the rumen of sheep receiving different energy sources. Animal Feed Science and Technology 63, 333-340.

Cone, J. W.; Van Gelder, A. H., 1999: Influence of protein fermentation on gas production profiles. Animal Feed Science and Technology 76, 251-264.

Cruz Soto, R.; Muhammed Samirah, A.; Newbold, C. J.; Stewart, C. S.; Wallace, J., 1994: Influence of peptides, amino acids and urea on microbial activity in the rumen of sheep receiving grass hay and on the growth of rumen bacteria in vitro. Animal Feed Science and Technology 49, 151-161.

Demeyer, D. I., 1991: Quantitative aspects of microbial metabolism in the rumen and hindgut. In: J. P. Jouany (ed.), Rumen Microbial Metabolism and Ruminant Digestion. INRA Editions, Paris, France, pp. 217-237.

Eschenlauer, S. C. P.; Mckain, N.; Walker, N. D.; Mcewan, N. R.; Newbold, C. J.; Wallace, R. J., 2002: Ammonia production by ruminal microorganisms and enumeration, isolation, and characterization of bacteria capable of growth on peptides and amino acids from the sheep rumen. Applied and Environmental Microbiology 68, 4925-4931.

Goering, M. K.; Van Soest, P. J., 1970: Forage Fiber Analysis (Apparatus, Reagents, Procedures and Some Applications). Agricultural Handbook, n 379 . Agricultural 
Research Services, USDA, Washington, DC, USA.

Griswold, K. E.; Mackie, R., 1997: Degradation of protein and utilization of the hydrolytic products by a predominant ruminal bacterium, Prevotella ruminicola B 1(4). Journal of Dairy Science 80, 167175.

Griswold, K. E.; Hoover, W. H.; Miller, T. K.; Thayne, W. V., 1996: Effect of form of nitrogen on growth of ruminal microbes in continuous culture. Journal of Animal Science 74, 483-491.

Hook, S. E.; Wright, A. D. G.; McBride, B. W., 2010: Review article. Methanogens: methane producers of the rumen and mitigation strategies. Archaea 2010, Article ID 945785, 11 pages.

Hume, I. D., 1970: Synthesis of microbial protein in the rumen. II. A response to higher volatile fatty acids. Australian Journal of Agricultural Research 21, 297 304.

Jentsch, W.; Schweigel, M.; Weissbach, F.; Scholze, H.; Pittroff, W.; Derno, M., 2007: Methane production in cattle calculated by the nutrient composition of the diet. Archives of Animal Nutrition 61, 10-19.

Johnson, K. A.; Johnson, D. E., 1995: Methane emissions from cattle. Journal of Animal Science 73, 2483-2492.

Kim, M.; Morrison, M.; Yu, Z., 2011: Phylogenetic diversity of bacterial communities in bovine rumen as affected by diets and microenvironments. Folia Microbiologica 56, 453-458.

Knapp, J. R.; Laur, G. L.; Vadas, P. A.; Weiss, W. P.; Tricarico, J. M., 2014: Invited review: enteric methane in dairy cattle production: quantifying the opportunities and impact of reducing emissions. Journal of Dairy Science $\mathbf{9 7}$, 3231-3261.

Kumar, S.; Choudhury, P. K.; Carro, M. D.; Griffith, G. W.; Dagar, S. S.; Puniya, M.; Calabro, S.; Ravella, S. R.; Dhewa, T.; Upadhyay, R. C.; Sirohi, S. K.; Kundu, S. S.; Wanapat, M.; Puniya, A. K., 2014: New aspects and strategies for methane mitigation from ruminants. Applied Microbiology and Biotechnology 98, 31-34.
Martínez, M. E.; Ranilla, M. J.; Tejido, M. L.; Ramos, S.; Carro, M. D., 2010: The effect of the diet fed to donor sheep on in vitro methane production and ruminal fermentation of diets of variable composition. Animal Feed Science and Technology 158, 126-135.

Mateos, I.; Ranilla, M. J.; Tejido, M. L.; Saro, C.; Kamel, C.; Carro, M. D., 2013: The influence of diet on the effectiveness of garlic oil and cinnamaldehyde to manipulate in vitro ruminal fermentation and methane production. Animal Production Science 53, 299-307.

Merry, R. J.; Mcallan, A. B.; Smith, R. H., 1990: In vitro continuous culture studies on the effect of nitrogen source on rumen microbial growth and fibre digestion. Animal Feed Science and Technology 31, 55-64.

Molina-Alcaide, E.; Weisbjerg, M. R.; Hvelplund, T., 1996: Degradation characteristics of shrubs and the effect of supplementation with urea or protein on microbial production using a continuous-culture system. Journal of Animal Physiology and Animal Nutrition $\mathbf{7 5}$, 121-132.

Moss, A. R.; Jouany, J. P.; Newbold, J., 2000: Methane production by ruminants: its contribution to global warming. Annales de Zootechnie 49, 231-253.

de Oliveira, S. G.; Berchielli, T. T.; Pedreira, M. S.; Primavesi, O.; Frighetto, R.; Lima, M. A., 2007: Effect of tannin levels in sorghum silage and concentrate supplementation on apparent digestibility and methane emission in beef cattle. Animal Feed Science Technology 135, 236248.

Ørskov, E. R., 1982: Protein Nutrition in Ruminants. Academic Press, London.

Pinares-Patiño, C. S.; Ulyatt, M. J.; Lassey, K. R.; Barry, T. N.; Holmes, C. W., 2003: Persistence of differences between sheep in methane emission under generous grazing conditions. The Journal of Agricultural Science 140, 227-233.

Poulsen, M.; Schwab, C.; Jensen, B. B.; Engberg, R. M.; Spang, A.; Canibe, N.; Hojberg, O.; Milinovich, G.; Fragner, L.; Schleper, C.; Weckwerth, W.; Lund, P.;
Schramm, A.; Urich, T., 2013: Methylotrophic methanogenic Thermoplasmata implicated in reduced methane emissions from bovine rumen. Nature Communications 4, 1428.

Ranilla, M. J.; Carro, M. D.; López, S.; Newbold, J. C.; Wallace, J., 2001: Influence of $\mathrm{N}$ source on the fermentation of fibre from barley straw and sugarbeet pulp by ruminal micro-organisms in vitro. British Journal of Nutrition 86, 717-724.

SAS Institute, 2012: SAS/STAT ${ }^{\circledR} 12.2$ User's $^{\prime}$ Guide. SAS Inst, Cary, NC, USA.

Satter, L. D.; Slyter, L. L., 1974: Effect of ammonia concentration on rumen microbial protein production in vitro. British Journal of Nutrition 74, 199-208.

Shreck, A. L.; Aluthge, N. D.; Jennings, J. S.; Fernando, S. C.; Cole, N. A., 2015: Effect of protein supplementation to low-quality forage diets on enteric methane production and ruminal microbial community structure of beef steers. Journal of Animal Science $\mathbf{9 3}$ (Suppl. 3), 770.

Stewart, C. S., 1977: Factors affecting the cellulolytic activity of rumen contents. Applied Microbiology and Biotechnology 33, 497-502.

Van Soest, P. J.; Robertson, J. B.; Lewis, B. A., 1991: Methods for dietary fiber, neutral detergent fiber, and nonstarch polysaccharides in relation to animal nutrition. Journal of Dairy Science $\mathbf{7 4}$, 3583-3597.

Wallace, R. J.; Cotta, M. A., 1988: Metabolism of nitrogen-containing compounds. In: P. N. Hobson (ed.), The Rumen Microbial Ecosystem. Elsevier Applied Science, London, pp. 217-250.

Wang, W. J.; Yang, W. R.; Wang, Y.; Song, E. L.; Liu, X. M.; Wan, F. C., 2013: Effects of soybean small peptides on rumen fermentation and on intestinal and total tract digestion of Luxi Yellow cattle. Asian-Australasian Journal of Animal Sciences 26, 72-81.

Weatherburn, M. W., 1967: Phenol-hypochlorite reaction for determination of ammonia. Analytical Chemistry 39, 971-974. 